\title{
PENGARUH PUPUK FOSFAT TERHADAP PERTUMBUHAN DAN PRODUKSI MENTIMUN JEPANG (Cucumis sativus L.)
}

\author{
Oksilia $\left.{ }^{1}{ }^{\star}\right)$, Silahuddin Alby ${ }^{1)}$ \\ 1) Dosen Program Studi Agroteknologi Fakultas Pertanian Universitas Tamansiswa Palembang \\ "Email: oksilia@gmail.com
}

\begin{abstract}
This study aims to determine the effect of phosphate fertilizer on the growth and production of Japanese cucumber (Cucumis sativus $\mathrm{L}$ ) in polybags. The design used was a randomized block design (RBD) with 6 (six) treatments for phosphate fertilizer, consisting of $0,15,20,25,30,35 \mathrm{~g}$ SP36 / polybag. Each treatment was repeated 4 times.

The results of this study indicate that the application of phosphate fertilizer has a very significant effect on the number of male flowers per polybag and has a significant effect on the number of female flowers per polybag, number of fruits per polybag, fresh weight of fruit per polybag and no significant effect on plant height. Overall Japanese cucumber with phosphate fertilizer $25 \mathrm{~g} \mathrm{SP36} \mathrm{/}$ polybag (P3) treatment gave better results compared to the other treatments.

Keyword: Japanese cucumber, fertilizer, phosphate
\end{abstract}

\begin{abstract}
ABSTRAK
Penelitian ini bertujuan untuk mengetahui pengaruh pupuk fosfat terhadap pertumbuhan dan produksi mentimun Jepang (Cucumis sativus $L$ ) di polibeg. Rancangan yang digunakan adalah rancangan acak kelompok (RAK) dengan 6 (enam) perlakuan dosis pupuk fosfat, yang terdiri dari 0 , 15, 20, 25, 30, $35 \mathrm{~g}$ SP36/polibeg. Masing-masing perlakuan diiulang sebanyak 4 kali.

Hasil penelitian ini menunjukkan, bahwa pemberian pupuk fosfat berpengaruh sangat nyata terhadap jumlah bunga jantan per polibeg dan berpengaruh nyata terhadap jumlah bunga betina per polibeg, jumlah buah per polibeg, berat segar buah per polibeg serta berpengaruh tidak nyata terhadap tinggi tanaman. Secara keseluruhan mentimun jepang dengan perlakuan pupuk fosfat 25 g SP36/polibeg $\left(\mathrm{P}_{3}\right)$ memberikan hasil yang lebih baik dibandingkan dengan perlakuan yang lainnya.
\end{abstract}

Kata kunci: Mentimun Jepang, fosfat,pupuk

\section{PENDAHULUAN}

Indonesia merupakan negara agraris yang beriklim tropis dan memiliki beraneka jenis tanaman Hortikultura. Diantara tanaman hortikultura yang mempunyai peranan penting dalam peningkatan gizi adalah sayur-sayuran. Sayuran merupakan bahan makanan yang sangat erat kaitannya dengan kesehatan manusia, sebab sayuran banyak mengandung vitamin dan mineral yang sangat dibutuhkan oleh tubuh manusia, seperti adanya Vitamin $A$, Vitamin B, Vitamin C, Vitamin D, Vitamin E, dan Vitamin K (Williams et al., 1993).

Tanaman mentimun (Cucumis sativus L.) termasuk tanaman hortikultura dan merupakan sayuran buah yang banyak disukai orang. Buah mentimun mengandung Vitamin A, Vitamin B, dan Vitamin C. Biasanya buah mentimun dimakan mentah dan dalam bentuk olahan, seperti rujak, asinan, acar, dan lalap (Anonim, 1993). 
Dalam $100 \mathrm{~g}$ mentimun mengandung energy 12,00 kalori, $0,60 \mathrm{~g}$ protein, $0,20 \mathrm{~g}$ lemak, 2,40 g karbohidrat, 0,50 g serat, 19,00 mg kalsium, 12,00 mg fosfor, 122,00 mg kalium, 0,40 zat besi, $5,00 \mathrm{mg}$ natrium, $0,071 \mathrm{~g}$ vitamin a, 0,02 mg vitamin $B 1,0,02$ mg vitamin $B 2,0,10$ mg niocin, 10,00 mg vitamin $\mathrm{C}$, dan $96,10 \mathrm{~g}$ air (Anonim dalam Rukmana, 1994).

Pada tahun 2.000 jumlah penduduk Indonesia di perkirakan akan mencapai lebih dari 200 juta jiwa, maka diperkirakan jumlah persediaan konsumsi sayuran juga akan meningkat (Sunarjon et al., 1989). Salah satu sayuran yang perlu ditingkatkan adalah mentimun. Usaha yang mungkin diterapkan untuk mencukupi kebutuhan mentimun ialah meningkatkan produktivitas lahan yang di tanam dan varietas yang digunakan.

Salah satu jenis mentimun yang merupakan verietas komersil yaitu mentimun varietas jepang. Dibandingkan dengan mentimun yang umum berkembang di Indonesia, varietas tersebut mempunyai rasa yang lebih manis, kadar air sedikit, bentuknya lebih panjang dan warnanya lebih hijau (Anonim, 1993). Mentimun Jepang adalah jenis mentimun hibrida yang sangat disukai masyarakat jepang. Jepang mengimpor sebagian dari kebutuhannya dari negara lain, karena keterbatasan lahan (Ferita, 1992). Teknik budidaya mentimun Jepang tidak jauh berbeda dengan mentimun biasa sehingga dapat diusahakan di Indonesia.

Indonesia sebagai negara produsen mentimun Jepang pada saat ini hanya mampu memproduksi rata-rata $3 \mathrm{~kg}$ per tanaman. Hasil ini masih jauh lebih rendah bila dibandingkan dengan produksi negara Jepang, yaitumampu mencapai rata-rata $10 \mathrm{~kg}$ per tanaman, karena teknologi budidayanya jauh berbeda dan lebih maju. Namun dengan teknologi yang sederhana pun mampu meningkatkan produksi dan memperbaiki mutu buah (Anonim, 1990).

Dalam usaha meningkatkan hasil tanaman mentimun selain menggunakan varietas unggul (Mentimun Jepang), produktivitas laha juga harus ditingkatkan. Produktivitas lahan dapat ditingkatkan dengan cara pelaksanaan pemberian pupuk. Menurut Sarief (1986), pemupukan merupakan salah satu cara untuk memperbaiki kesuburan tanah, sehingga tanaman dapat memperoleh hara untuk pertumbuhannya. Dari sejumlah unsur hara, Fosfor $(P)$ merupakan salah satu unsur hara yang penting bagi pertumbuhan tanaman.

Kekurangan unsur Fosfor $(P)$ dapat mempengaruhi ketersediaan unsur hara lain bagi tanaman. Menurut Buckman dan Brady (1982), kegunaan Fosfor bagi pertumbuhan dan perkembangan tanaman adalah mempercepat pertumbuhan akar semai, mempercepat dan memperkuat pertumbuhan tanaman muda serta memperkokoh tanaman, mempercepat pembuangan dan pembuahan termasuk pembuahan biji, meningkatkan produksi bijibijian, kekebalan tanaman terhadap penyakit tertentu. Ditambahkan oleh Sarief (1986), bahwa fosfor merupakan bagian dari inti sel sangat penting dalam pembelahan sel dan perkembangan jaringan meristem.

Masalah yang dihadapi dalam pemberian Fosfor adalah sebagian Fosfor dalam tanah umumnya tidak tersedia untuk tanaman (Buckman dan Brady, 1982) Ditambahkan oleh Hakim et al., (1986), bahwa permasalahan yang umum di hadapi oleh Fosfor dalam tanah adalah tidak semua Fosfor tanah dapat segera tersedia untuk tanaman. Pada tanah masam dengan $\mathrm{pH}$ kurang dari 5,0 Fosfor akan diikat sebagai Fosfor $\mathrm{Fe}, \mathrm{Al}$, dan $\mathrm{Mn}$ yang tidak larut dalam air sehingga ketersediaannya dalam tanah berkurang (Tirto utomo dan Simanungkalit, 1988) untuk mendapatkan pertumbuhan dan produksi yang tinggi diperlukan masukan pupuk Fosfor yang tinggi.

Menurut Buntan et al., (1993), pemberian pupuk dalam jumlah yang jauh lebih besar daripada kebutuhan tanaman itu menyebabkan pemupukan $P$ menjadi tidak efisien. Agar pemakaian pupuk $P$ lebih efisien, ynag perlu diperhatikan adalah dalam bentuk apa pupuk $P$ itu diberikan. Pupuk $P$ dalam bentuk aslinya (butiran) adalah pupuk yang lambat larut dan lambat tersedia bagi tanaman. Agar pupuk $P$ yang diberikan segera dapat diserap oleh akar dan efisien dalam pemakaian pupuk $P$, maka pupuk padat yang akan diberikan dicairkan atau dilarutkan terlebih dahulu dalam air (Silalahi dan 
Lindung, 1992). Pemberian pupuk $P$ yang dilarutkan tersebut dahulu menyebabkan pupuk $P$ yang diberikan berada pada fase cair. Pada fase cair, $P$ akan diserap oleh akar tanaman pada saat akar tanaman menyerap air (Agustina, 1990). Hal ini sejalan dengan Hari dalam Sarief (1986), menyatakan bahwa air dibutuhkan sebagai pelarut dan pembawa unsur hara dari akar ke atas bagian tumbuhan.

Menurut Rukmana (1994), jumlah Fosfat yang dibutuhkan pada mentimun hibrida Jepang $500 \mathrm{~kg}$ TSP/ha yang setara dengan $25 \mathrm{~g}$ SP36/polibeg. Masalah yang dihadapi sekarang adalah bagaimana pengaruh pupuk fosfat terhadap pertumbuhan dan produksi mentimun jepang. Maka perlu diadakan penelitian mengenai pengaruh pupuk fosfat terhadap pertumbuhan dan produksi mentimun Jepang (Cucumis sativus L.) di polibeg.

\section{METODE PENELITIAN}

Penelitian ini dilakukan di Kebun Percobaan Fakultas Pertanian Universitas Tamansiswa Palembang.

Alat-alat yang digunakan dalam penelitian adalah Polibeg ukuran $45 \times 50 \mathrm{~cm}$, parang timbangan, cangkul, label, tali rapia, ajir bamboo, jarring, ayakan, ember, handsprayer, dan alat-alat tulis.

Bahan yang digunakan dalam penelitian ini adalah Benih mentimun Jepang varietas Pnuket 747, pupuk Urea, pupuk $\mathrm{KCl}$, pupuk SP36, Furadan 3G, Dithane M45, Supracide 40 EC, dan pupuk kandang.

Penelitian ini menggunakan Rancangan Acak Kelompok (RAK) dengan 6 (enam) perlakuan dosis pupuk fosfat $(\mathrm{P})$. Masingmasing perlakuan dengan 4 (empat) ulangan. Rincian masing-masing per lahan adalah sebagai berikut :

$$
\begin{aligned}
& P_{0}=0 \mathrm{~g} \text { SP36/polybeg } \\
& P_{1}=15 \mathrm{~g} \text { SP36/polibeg } \\
& P_{2}=20 \mathrm{~g} \text { SP36/polibeg } \\
& P_{3}=25 \mathrm{~g} \text { SP36/polibeg } \\
& P_{4}=30 \mathrm{~g} \mathrm{SP36/polibeg} \\
& P_{5}=35 \mathrm{~g} \text { SP36/polibeg }
\end{aligned}
$$

Data yang diperoleh dari hasil penelitian dianalisis statistik dengan menggunakan daftar analisis keragaman (Hanafiah, 1994)

\section{Prosedur Kerja}

\section{Persiapan Lahan}

Areal penelitian dipilih yang datar, kemudian dibersihkan dari tanaman pengganggu serta kotoran yang ada setelah itu pagar dengan jaring.

\section{Persiapan media tanam}

Polibeg yang digunakan berwarna hitam dengan ukuran $40 \times 50 \mathrm{~cm}$. Seminggu sebelum tanam, polibeg diisi dengan media campuran lapisan tanah atas jenis ultisol dengan pupuk kandang perbandingannya 2 : 1 . Sebelum dicampur dengan pupuk kandang tanah tersebut diayak terlebih dahulu. Setelah dicampur rata, lalu disemprot secara merata dengan larutan Dithane $\mathrm{m}-45$ dan Furadan $3 \mathrm{G}$.

\section{Persiapan benih dan penanaman}

Untuk mendapatkan benih yang baik maka benih harus diseleksi sebelum ditanamkan. Penyeleksian benih dapat dilakukan dengan cara merendamkan benih selama 15 menit, benih yang tenggelam di rendam kembali selama 24 jam, lalu dilakukan penanaman di dalam polibeg. Setiap lubang tanam diisi 2-3 benih mentimun jepang yang telah siap tanam.

\section{Pemupukan}

Pupuk yang digunakan adalah Urea 850 $\mathrm{kg} / \mathrm{ha}$ dan pupuk $\mathrm{KCl} 600 \mathrm{~kg} / \mathrm{ha}$. Sebagai pupuk awal diberikan Urea $150 \mathrm{~kg} / \mathrm{ha}$. Atau 7,5 g/polibeg dan pupuk $\mathrm{KCl} 150 \mathrm{~kg} / \mathrm{ha}$ atau 7,5 g/polibeg. Pupuk SP36 diberikan seluruh dosis pada saat tanam. Sisa pupuk Urea dan pupuk $\mathrm{KCl}$ diberikan dalam 3 tahap. Tahap I (pupuk susulan I) diberikan 10 hari setelah tanam, disebar di sekeliling tanaman sejauh lebih kurang $10 \mathrm{~cm}$ dari batang. Pupuk susulan II diberikan 10 hari setelah pupuk susulan I. Pupuk susulan III diberikan setelah 10 hari pupuk susulan II (Rukmana, 1994).

\section{Pemeliharaan}


a. Penyiraman, dilakukan setiap pagi dan sore hari jika hujan tidak turun disesuaikan dengan kebutuhan tanaman.

b. Penjarangan, dilakukan setelah tanaman berumur satu minggu dengan cara menyisakan satu tanaman yang baik pada setiap polibeg

c. Penyiangan, dilakukan setelah tanaman berumur dua minggu baik gulma yang terdapat disekitar polibeg.

d. Penyulaman, dilakukan setelah tanaman yang mati layu, rusak atau kurang baik pertumbuhannya. Penyulaman dilakukan setelah satu minggu setelah tanam.

e. Pemangkasan, dilakukan setelah tanaman memasuki awal fase generatif atau kira-kira berumur 37 hari yang disisakan $1,5 \mathrm{~m}$. Pemangkasan dilakukan supaya pertumbuhan vegetatif tanaman berhenti pada ketinggian 1,5 meter.

f. Pengendalian hama dan penyakit, dilakukan dengan pemberian pestisida Supracide 40 EC dan fungisida Dithane M-45. Penyemprotan dilakukan pada saat tanaman berumur satu minggu setelah tanam hingga dua minggu menjelang panen, dengan interval penyemprotan satu minggu sekali.

\section{Peubah yang diamati}

Pada penelitian ini pengamatan terhadap parameter-parameter yang dilakukan terhadap tanaman sampel sebanyak 1 tanaman untuk tiap perlakuan. Adapun parameter yang diamati adalah panjang tanaman, jumlah bunga jantan (buah), jumlah bunga betina (buah), jumlah buah, berat segar buah.

\section{HASIL DAN PEMBAHASAN}

\section{Hasil}

Hasil analisis keragaman (uji F) menunjukkan bahwa perlakuan pupuk fosfat berpengaruh sangat nyata terhadap jumlah bunga jantan perpolibeg dan berpengaruh nyata terhadap jumlah bunga betina perpolibeg, jumlah buah per polibeg, berat segar buah per polibeg serta pengaruh tidak nyata terhadap tinggi tanaman, yang secara rinci tertera pada Tabel 2.

Tabel 2. Hasil analisis keragaman peubah yang diamati.

\begin{tabular}{llc}
\hline No. & Peubah yang diamati & Pupuk Fosfat \\
\hline 1. & Panjang tanaman & 0,46 tn \\
2. & Jumlah bunga jantan & $5,61^{* *}$ \\
3. & Jumlah bunga betina & $3,28^{*}$ \\
4. & Jumlah buah & $3,16^{*}$ \\
5. & Berat segar buah & $2,91^{*}$
\end{tabular}

Keterangan : ${ }^{*}=$ berpengaruh nyata

${ }^{* *}=$ berpengaruh sangat nyata

tn = berpengaruh tidak nyata

\section{Panjang Tanaman}

Data hasil pengamatan tinggi tanaman menunjukkan bahwa perlakuan pupuk fosfat yang diberikan tidak menunjukkan pengaruh yang nyata.

\section{Jumlah bunga jantan per polibeg}

Data hasil pengamatan dan hasil analisis peragaman terhadap jumlah bunga jantan per polibeg menunjukkan, bahwa perlakuan pupuk fosfat $25 \mathrm{~g}$ SP36/polibeg $\left(\mathrm{P}_{3}\right)$ meningkatkan jumlah bunga jantan per polibeg secara nyata dibandingkan dengan perlakuan lainnya, tetapi berbeda tidak nyata dengan perlakuan $20 \mathrm{~g}$ SP36/polibeg $\left(P_{2}\right)$.

Tabel 3. Pengaruh pupuk fosfat terhadap jumlah bunga jantan per polibeg.

\begin{tabular}{ccc}
\hline $\begin{array}{c}\text { Pupuk fosfat } \\
\text { (g/polibeg) }\end{array}$ & $\begin{array}{c}\text { Jumlah bunga } \\
\text { jantan } \\
\text { (buah/polibeg) }\end{array}$ & $\begin{array}{c}\text { BNT 5\% } \\
=4,60\end{array}$ \\
\hline 0 & 50,00 & $\mathrm{a}$ \\
15 & 53,75 & $\mathrm{ab}$ \\
20 & 56,25 & $\mathrm{bc}$ \\
25 & 60,00 & $\mathrm{C}$ \\
30 & 51,25 & $\mathrm{a}$ \\
35 & 53,00 & $\mathrm{ab}$ \\
\hline Keterangan: Angka-angka yang dikuti oleh huruf yang \\
\multicolumn{3}{c}{ sama berarti berbeda tidak nyata. }
\end{tabular}

Jumlah bunga jantan per polibeg pada perlakuan pupuk fosfat $15 \mathrm{~g} \mathrm{SP36/polibeg}\left(\mathrm{P}_{1}\right)$, $20 \mathrm{~g} \mathrm{SP36/polibeg}\left(\mathrm{P}_{2}\right)$ dan $35 \mathrm{~g}$ SP36/polibeg $\left(P_{5}\right)$ tidak menunjukkan perbedaan yang nyata, tetapi berbeda nyata dengan yang tanpa pupuk 
fosfat $\left(P_{0}\right)$ dan $30 \mathrm{~g}$ SP36/polibeg $\left(P_{4}\right)$. Dan diantara perlakuan yang tanpa pupuk fosfat $\left(P_{0}\right), 15 \mathrm{~g}$ SP36/polibeg $\left(P_{1}\right), 30 \mathrm{~g}$ SP36/polibeg $\left(P_{4}\right)$ dan 35 g SP36/polibeg $\left(P_{5}\right)$ tidak menunjukkan perbedaan yang nyata, seperti tertera pada Tabel 3.

\section{Jumlah bunga betina per polibeg}

Hasil uji BNT menunjukkan, bahwa perlakuan pupuk fosfat $25 \mathrm{~g}$ SP36/polibeg $\left(\mathrm{P}_{3}\right)$ meningkatkan jumlah bunga betina per polibeg secara nyata dibandingkan dengan perlakuan lainnya, kecuali berbeda tidak nyata dengan perlakuan pupuk fosfat $20 \mathrm{~g}$ SP36/polibeg $\left(P_{2}\right)$ dan 30g SP36/polibeg $\left(P_{4}\right)$. Jumlah bunga betina per polibeg pada perlakuan pupuk fosfat 20g SP36/polibeg $\left(P_{2}\right)$, 30g SP36/polibeg $\left(P_{4}\right)$ dan $35 \mathrm{~g}$ SP36/polibeg tidak menunjukkan perbedaan yang nyata, tetapi berbeda nyata dengan yang tanpa pupuk fosfat $\left(P_{0}\right)$ dan $15 \mathrm{~g}$ SP36/polibeg $\left(P_{1}\right)$.

Diantara perlakuan tanpa pupuk fosfat (P0), 15g SP36/polibeg (P1), 30g SP36/polibeg (P4) dan $35 \mathrm{~g}$ SP36/polibeg (P5) tidak menunjukkan perbedaan yang nyata, seperti tertera pada Tabel 4

Tabel 4. Pengaruh pupuk fosfat terhadap jumlah bunga betina per polibeg.

\begin{tabular}{ccc}
\hline $\begin{array}{c}\text { Pupuk fosfat } \\
\text { (g/polibeg) }\end{array}$ & $\begin{array}{c}\text { Jumlah bunga } \\
\text { betina } \\
\text { (buah/polibeg) }\end{array}$ & $\begin{array}{c}\text { BNT } 0,05= \\
2,19\end{array}$ \\
\hline 0 & 5,75 & a \\
15 & 6,00 & a \\
20 & 8,50 & bc \\
25 & 9,00 & $\mathrm{c}$ \\
30 & 7,50 & abc \\
35 & 6,75 & ab \\
\hline
\end{tabular}

Keterangan: Angka-angka yang diikuti oleh huruf yang sama berarti berbeda tidak nyata.

\section{Jumlah buah per polibeg}

Hasil uji BNT menunjukkan, bahwa perlakuan pupuk fosfat $25 \mathrm{~g}$ SP36/polibeg $\left(\mathrm{P}_{3}\right)$ meningkatkan jumlah buah per polibeg secara nyata dibandingkan dengan perlakuan yang tanpa pupuk fosfat $\left(P_{0}\right), 30 \mathrm{~g}$ SP36/polibeg $\left(P_{4}\right)$ dan 35g SP36/polibeg $\left(P_{5}\right)$, tetapi berbeda tidak nyata dengan perlakuan pupuk fosfat $15 \mathrm{~g}$ SP36/polibeg $\left(P_{1}\right)$ dan $20 \mathrm{~g}$ SP36/polibeg $\left(P_{2}\right)$.

Tabel 5. Pengaruh pupuk fosfat terhadap jumlah buah per polibeg.

\begin{tabular}{ccc}
\hline $\begin{array}{c}\text { Pupuk fosfat } \\
\text { (g/polibeg) }\end{array}$ & $\begin{array}{c}\text { Jumlah buah } \\
\text { (buah/polibeg) }\end{array}$ & $\begin{array}{c}\text { BNT }_{0,05}= \\
1,3\end{array}$ \\
\hline 0 & 2,0 & $\mathrm{a}$ \\
15 & 3,0 & $\mathrm{abc}$ \\
20 & 3,5 & $\mathrm{bc}$ \\
25 & 4,0 & $\mathrm{c}$ \\
30 & 2,5 & $\mathrm{ab}$ \\
35 & 2,0 & $\mathrm{a}$ \\
\hline
\end{tabular}

Keterangan: Angka-angka yang diikuti oleh huruf yang sama berarti berbeda tidak nyata.

Jumlah buah per polibeg pada perlakuan pupuk fosfat $15 \mathrm{~g}$ SP36/polibeg $\left(P_{1}\right)$ menunjukkan perbedaan yang nyata jika dibandingkan dengan perlakuan yang tanpa pupuk fosfat $\left(P_{0}\right)$ dan $35 \mathrm{~g}$ SP36/polibeg $\left(P_{5}\right)$, tetapi berbeda tidak nyata dengan perlakuan pupuk fosfat $20 \mathrm{~g} \mathrm{SP36/polibeg}\left(\mathrm{P}_{2}\right)$ dan $30 \mathrm{~g}$ SP36/polibeg $\left(P_{4}\right)$. Sedangkan perlakuan yang tanpa pupuk fosfat $\left(P_{0}\right)$ tidak menunjukkan perbedaan yang nyata dibandingkan dengan perlakuan pupuk fosfat $15 \mathrm{~g}$ SP36/polibeg $\left(\mathrm{P}_{1}\right)$, $30 \mathrm{~g} \mathrm{SP36/polibeg}\left(\mathrm{P}_{4}\right)$ dan $35 \mathrm{~g}$ SP36/polibeg $\left(P_{5}\right)$ seperti tertera pada Tabel 5.

\section{Berat segar buah per polibeg}

Hasil uji BNT menunjukkan, bahwa perlakuan pupuk fosfat $25 \mathrm{~g} \mathrm{SP36/polibeg} \mathrm{(P3)}$ meningkatkan berat segar buah polibeg secara nyata dibandingkan dengan perlakuan yang tanpa pupuk fosfat $\left(\mathrm{P}_{0}\right), 30 \mathrm{~g}$ SP36/polibeg $\left(\mathrm{P}_{4}\right)$ tetapi berbeda tidak nyata jika dibandingkan dengan perlakuan lainnya.

Berat segar buah per polibeg pada perlakuan pupuk fosfat $20 \mathrm{~g}$ SP36/polibeg tidak menunjukkan perbedaan yang nyata dengan perlakuan yang lainnya, kecuali berbeda nyata dengan perlakuan yang tanpa pupuk fosfat $\left(P_{0}\right)$ dan 25 g SP36/polibeg $\left(P_{3}\right)$. Namun demikian, antara perlakuan yang tanpa pupuk fosfat $\left(P_{0}\right)$, $15 \mathrm{~g}$ SP36/polibeg $\left(\mathrm{P}_{1}\right)$. Dan $30 \mathrm{~g}$ SP36/polibeg 
$\left(P_{4}\right)$ tidak menunjukkan perbedaan yang nyata, seperti tertera pada Tabel 6 .

Tabel 6. Pengaruh pupuk fosfat terhadap berat segar buah per polibeg

\begin{tabular}{ccc}
\hline $\begin{array}{c}\text { Pupuk fosfat } \\
\text { (g/polibeg) }\end{array}$ & $\begin{array}{c}\text { Berat segar buah } \\
\text { (buah/polibeg) }\end{array}$ & $\begin{array}{c}\text { BNT } 0,05= \\
5,05\end{array}$ \\
\hline 0 & 379,80 & a \\
15 & 533,04 & abc \\
20 & 712,86 & bc \\
25 & 769,54 & $\mathrm{c}$ \\
30 & 456,43 & ab \\
35 & 632,95 & bc \\
\hline
\end{tabular}

Keterangan: Angka-angka yang diikuti oleh huruf yang sama berarti berbeda tidak nyata.

\section{Pembahasan}

Di Indonesia mentimun merupakan sayuran yang sangat populer dan digemari oleh hampir seluruh masyarakat. Meskipun demikian kebanyakan usaha tani mentimun masih dianggap usaha sampingan, sehingga rata-rata hasil mentimun secara nasional masih rendah, yakni 3,5-4,8 ton per hektar (Rukmana, 1999).

Peningkatan produksi dan produktivitas mentimun penting artinya bagi pemenuhan kebutuhan pasar (konsumen) dalam negeri maupun luar negeri (ekspor). Oleh sebab itu, usaha meningkatkan produksi mentimun di dalam negeri perlu mendapatkan perhatian yang serius dimana tingkat kesuburan masih rendah. Menurut Nyakpa et al., (1988), pada tanah yang masam kelarutan $\mathrm{Al}, \mathrm{Fe}$, dan $\mathrm{Mn}$ yang tinggi pada tanah menyebabkan unsur Fosfat kurang tersedia bagi tanaman.

Hasil analisis keragaman menunjukkan bahwa perlakuan pupuk Fosfat berpengaruh sangat nyata terhadap jumlah bunga jantan per polibeg dan berpengaruh nyata terhadap jumlah bunga betina per polibeg, jumlah buah per polibeg dan berat segar buah per polibeg.

Hal ini disebabkan karena pupuk Fosfat berfungsi sebagai metabolisme energy seperti dalam fotosintesis dan aktivator enzim dan juga berguna untuk pembentukan bunga, buah serta mempercepat masa pemasakan dan peningkatan ketahanan terhadap kekeringan (Sutarto, 1993). Pada tinggi tanaman menunjukkan pengaruh tidak nyata, hal ini diduga pada saat pertumbuhan pupuk fosfat penggunaannya relative sedikit dan berpengaruh oelh jenis varietasnya.

Pemberian pupuk fosfat $25 \mathrm{~g}$ SP36/polibeg $\left(\mathrm{P}_{3}\right)$ meningkatkan jumlah bunga jantan per polibeg secara nyata dibandingkan dengan perlakuan lainnya, tetapi berbeda tidak nyata dengan perlakuan $20 \mathrm{~g}$ SP36/polibeg $\left(P_{2}\right)$. Banyaknya bunga jantan yang dihasilkan tanaman mentimun jepang ada perlakuan pupuk Fosfat $25 \mathrm{~g} \mathrm{SP36/polibeg} \mathrm{adalah} \mathrm{menunjukkan}$ respon yang baik dari tanaman terhadap pemupukan fosfat.

Unsur fosfat sangat berperan dalam pembentukan bunga pada fase reproduktif. Dimana unsur fosfat setelah memasuki fase refroduktif membantu menghasilkan bunga, buah yang sehat dan normal (Anonim, 1994). Namun demikian penambahan pupuk fosfat menjadi $30 \mathrm{~g}$ SP36/polibeg dan $35 \mathrm{~g}$ SP36/polibeg menyebabkan turunnya jumlah bunga jantan. Hal ini diduga terjadi ketidakseimbangan hara didalam tanah akibat penambahan pupuk fosfat tanpa di imbangi pupuk $\mathrm{N}$ dan $\mathrm{K}$.

Jumlah bunga jantan antara perlakuan pemberian pupuk fosfat $25 \mathrm{~g} \mathrm{SP36/polibeg}\left(\mathrm{P}_{3}\right)$ dan $20 \mathrm{~g} \mathrm{SP36/polibeg}\left(P_{2}\right)$ tidak berbeda nyata, diduga berkaitan dengan pemberian pupuk fosfat . Pemberian pupuk fosfat pada tanah erat kaitannya dengan ketersediaan fosfat bagi tanaman dalam tanah, dimana tanaman akan lebih mudah menyerap unsur fosfat dalam bentuk larutan. Hal ini sesuai dengan silalahi dan Lindung (1992), menyatakan bahwa pupuk yang diberikan segera dapat diserap oleh akar dan efisiensi dalam bentuk larutan.

Hasil pengamatan jumlah bunga betina per polibeg menunjukkan bahwa pemberian pupuk fosfat $25 \mathrm{~g}$ SP36/polibeg $\left(\mathrm{P}_{3}\right)$ meningkatkan jumlah bunga betina per polibeg secara nyata dibandingkan dengan perlakuan lainnya, tetapi berbeda tidak nyata dengan perlakuan pupuk fosfat $20 \mathrm{~g}$ SP36/polibeg $\left(P_{2}\right)$ dan $30 \mathrm{~g}$ SP36/polibeg $\left(\mathrm{P}_{4}\right)$.

Hal ini diduga terbentuknya bunga betina merupakan respons dari pertumbuhan dan perkembangan kuncup bunga pada fase 
reproduktif yang dipengaruhi oleh unsur fosfat yang diberikan. Fosfat yang diserap sangat berperan aktif dalam mentransfer energy ke sel, sehingga memperlancar fotosintesis yang akan mengubah karbohidrat menjadi lipid, protein dan molekul-molekul organik.

Disamping memiliki peranan dalam pembentukan bunga, unsur fosfat juga dapat meningkatkan penyerapan unsur lain seperti Nitrogen dan Kalium. Diduga kalium juga berperan dalam meningkatkan proses fotosintesis. Menurut Kacson et al., (1986) dalam Yusnina (1995) pada umumnya kalium berperan dalam aktifitas enzim pengatur membuka dan menutupnya stomata, proses fotosintesis dan translokasi menuju ke titik tumbuh.

Hasil pengamatan jumlah per polibeg dan hasil analisis keragaman menunjukkan bahwa perlakuan pupuk fosfat $25 \mathrm{~g}$ SP36/polibeg yaitu 769,54 meningkatkan jumlah buah per pollibeg secara nyata dibandingkan dengan perlakuan yang tanpa pupuk fosfat yaitu $379,80,30 \mathrm{~g}$ SP3/polibeg $=456,43$ dan $\mathrm{g}$ SP36/polibeg $=$ 632,95, tetapi berbeda tidak nyata terhadap pemupukan g SP36/polibeg 533,04 dan $20 \mathrm{~g}$ SP36/polibeg $=712,86$. Rata-rata buah yang tertinggi dihasilkan oleh tanaman yang diberikan perlakuan pupuk fosfat $25 \mathrm{~g} \mathrm{SP36/polibeg} \mathrm{yaitu}$ 769,549 .

Hal ini disebabkan karena pupuk fosfat berfungsi sebagai metabolisme energi seperti dalam fotosintesis dan aktivator enzim dan juga berguna untuk pembentukan bunga, buah, biji serta mempercepat masa pemasakan dan peningkatan ketahanan tanaman tehadap kekeringan (Sutarto, 1993). Dengan penambahan dosis pupuk fosfat yang lebih tinggi cenderung menurunkan hasil jumlah buah. Hal ini diduga dengan penambahan unsur fosfat yang tinggi akan bersifat racun bagi tanaman.

Menurut Bidwell (1979), fosfat berperan dalam tanaman sebagai pembangun nucleoprotein dalam inti sel. Pembentukan selsel baru hanya dapat berlangsung dengan pembelahan inti sel. Dengan demikian bila kekurangan atau kelebihan fosfat pada media tanaman, pertumbuhan tanaman akan menghambat proses pembelahan sel dan akibatnya pertumbuhan akan terhambat.

Hasil pengamatan dan analisis keragaman berat segar buah per polibeg menunjukkan bahwa pemupukan $25 \mathrm{~g}$ SP36/polibeg (P3) meningkatkan berat segar buah yang tertinggi, diduga erat kaitannya dengan jumlah buah yang terbentuk dan panen. Dimana semakin banyak jumlah buah per polibeg yang dipanen, maka berat segar buah per polibeg cenderung meningkat.

Berat bersih ini berhubungan dengan pemberian pupuk fosfat yang sesuai dan mudah diserap oleh tanaman. Fosfat yang disetiap tanaman sangat berperan aktif dalm mentransfer energy kedalam sel yang akan memperlancar fotosintesis yang akan mengubah karbohidrat menjadi lipid, protein dan molekul-molekul organik. Berat segar buah lebih ditentukan oleh besarnya akumulasi bahan organik. Buah yang dihasilkan akan terbentuk sempurna apabila akumulasi karbohidrat cukup tersedia (Saptarini et al.,1986dalam Ferita, 1992).

Meningkatkan proses fotosintesis yang akan mendorong terjadinya proses pemupukan fotosintesis yang kemudian di angkut ke dalam buah. Rendahnya hasil berat segar buah per polibeg mentimun jepang diduga akibat serangan hama yang menyebabkan pertumbuhan tanaman terhambat dan mengakibatkan banyak buah menjadi gugur.

\section{KESIMPULAN}

Dari hasil penelitian ini dapat diambil kesimpulan sebagai berikut:

1. Pemberian pupuk fosfat tidak berpengaruh terhadap pertumbuhan panjang tanaman.

2. Pemberian pupuk fosfat $25 \mathrm{~g}$ SP36/polibeg (P3) memberikan hasil yang terbaik terhadap produksi mentimun jepang dengan hasil $769,549 \mathrm{~g}$.

\section{DAFTAR PUSTAKA}

Agustina, L. 1990. Nutrisi Tanaman. Rineka Cipta. Jakarta. 
Anonim. 1990. Info Agribisnis Mentimun Jepang. Majalah Trubus No. 245 Th. XXI April. Jakarta.

Anonim. 1993. Sayur Komersial. Penebar Swadaya Jakarta.

Buckman, H. O. dan N.C.Brady. 1982. IImu Tanah (terjemahan). Bharatara Karya Aksara. Jakarta.

Buntan, A.I. Anas, K. Idris dan L. Gunanto. 1993. Pengaruh Bakteri Pelaut Fosfat dan Kompos Terhadap Serapan P dan Efisiensi Pemupukan $P$ pada Jagung. Bulletin Penelitian Pertanian Meros. Balai Penelitian Pangan Maros.

Ferita, I. 1992. Pengaruh Saat Pemangkasan Cabang dan Pemberian Reterdan Uniconazole Terhadap Pertumbuhan dan Produksi Mentimun Jepang (Cucumis sativus L.) Thesis Pasca Sarjana KPK IPBUNAND. Padang.

Hakim, N., M. Y. Nyakpa, A. M. Lubis, S.G. Nugroho, M.A. Diha, G.B. Hong dan H. H Bailey. 1986. Dasar-dasar IImu Tanah. Universitas Lampung.

Hanafiah, K.A. 1994. Rancangan Percobaan Teori dan Aplikasi. PT. Raja Grafindo Persada. Jakarta.

Rukmana, R. 1994. Budidaya Mentimun, Kanisius. Yogyakarta.
Sarief, S. 1986. Kesuburan dan Pemupukan Tanah Pertanian. Pustaka Buana. Bandung.

Setymidjaja, D. 1986. Pupuk dan pemupukan. CV. Simplex. Jakarta.

Silalahi, S. dan Lindung. 1992. Pemakaian Pupuk Padat dan Pupuk Padat yang Dicairkan pada Tanaman Cabe. Balai Latihan Pegawai Pertanian (BLPP) Lubuk Ruso. Jambi

Sunarjono, H., Widianani, Ginting, M. dan Budiarti, R. 1989. Penampakan Kelamin Bunga Betina pada Tanaman Timun. Bulletin Penelitian Hortikultura. Vol. XVII No. 4 Th. 1989.

Sunaryono, H. 1990. Kunci Bercocok Tanam Sayur-sayuran penting di Indonesia. Sinar Baru. Bandung.

Tirtoutomo, S. dan R.D.M. Simanungkalit. 1988. Pengaruh Pemberian Kapur dan Fosfat Terhadap Serapan P. Pertumbuhan dan Hasil Kedelai Pada Tanah Ultisol Sukamandi. Media Penelitian Sumandi. No. 6 Th 1988.

Williams, C.N., J.O. Uzo dan W.T.H. Peregrine. 1993. Produksi Sayuran di Daerah Tropika (terjemahan). Gadjah Mada University Press. Yogyakarta. 